\title{
The Effect of Nandralone Decanoate on Athletes Fertility
}

\author{
Isam Mohammed Jaber Zabiba ${ }^{\mathrm{a}}$ Amer J Hadi $^{\mathrm{b}}$ Aqeel khaleel ibraheem ${ }^{\mathrm{c}}$
}

\author{
${ }^{a}$ Al-Qasam Green University, College of Vet. medicine \\ ${ }^{b}$ Al-Qasam Green University, College of Biomedical Science \\ ${ }^{c}$ Ministry of education,Babylon.
}

isam.zabiba@yahoo.comalqassimi2011@yahoo.comaqee18077@yahoo.com

Submission date:- 19/12/2018 Acceptance date:- 9/1/2018 Publication date:- 18/11/2018

Keywords: Nandralone Decanoate, fertility, athletes

\begin{abstract}
Anabolic androgenic steroids (AAS)",(Nandrolone Decanoate) the treatments most widely abused commonly for improving athletic ability, appearance or muscle mass, athletes, coaches, and physicians should be aware of their harmful side effects .liquorice extract consider important medical plant due to rich in antioxidants, flavonoids, phenolic and alkaloids that Supports the general health of the body. In this study we compare between two groupes of young athletes from Al-Qasam city, each group containes from six athletes, the first group they taken Nandrolone Decanonate with dose $50 \mathrm{mg}$, I.M. for three time weakly and persistence in a period at least two month, the secound group the without any treatment are useing as a countrol group. The result showing that athletes who taken Nandralone at least two month there is have low elevation in liver enzyme but there is no significant differences in GPT ,GOT, ALP, as well as decreased the levels of mean "serum FSH, LH and testosterone.

\section{1-Introduction}

Anabolic-androgenic steroids (AAS) are synthetic compounds have two action androgenic and anabolic. These effects depend on chemical structure of testosterone. Some synthetic compound possess greater anabolic such as Nandrolone Decanoate, stanazole 4:1, 6:1 respectively rather than natural testosterone1:1 [1].AAS used for treatment in different conditions such as delay puberty, reproductive system dysfunction, breast cancer and anemia [2]. The side effects for using AAS is estrification of testosterone at the 17- $\beta$-hydroxy location, [3]. Moreover hypogonadism, osteoporosis cachexia, HIV infection and protein deficience may occur after bad surgical interference, [4],[5].

The AAS clinicaly has been replaced by erythropoietin due to its sever side effect. As well as the athletes appear aggressiveness and confidence, [6]. Moreover some athletes suffer from abuse by taking very high dose of AAS usually range from 10-100 times dose,[3]. Inhibition for leutenizing hormones (L.H) and follicules stimulated hormones (FSH) occured [8],[7]. Many AAS may either develop or limit the effect such as Dianabol, Oxymetolone and Oxandralone as tablets for oral medication, Nandralone and Boldenone are the most common AAS which resulted from removing C-19 methyle group from testosterone [9]. Nandralone most widely used with dose 25- 200mg/ml, I.M. or $\mathrm{S} / \mathrm{C}[10],[11]$. There are many research is done on AAS to see the effect with supraphysiological dose of AAS such as infraction, myocardial, sudden death, pulmonary embolism, congestive heart failure, atrial fibrillation and ventricular arrhythmia,[13],[12]. Although [14] refer that Nandralone when is given for 3 to 6 months showed significant increase in muscle force, nerve conduction and force contraction but failed to support anabolic effect (muscle cell size, muscle fiber type and satellite cell count). Nandralone consider potent procarcinogenic for hepatocellular carcinoma, fluid retention that increase over weight and prostate cancer, addition to increase incidence of viral hepatitis and AIDS infection between athletes due to shared with same needle and syringe with abscess and ulceration, alteration libido, testes atrophy, gynecomasia, [15].
\end{abstract}




\section{2- Aims of study:}

In spite of of the effort many researches utilize on the effects of AAS compounds on different body systems, these effects of supraphysiologic doses of AAS compounds remain unclear. Subsequently, the present study was conducted to investigate the effects of nandrolone decanoate on serum levels of "gonadotropins FSH and LHand testosterone" [16].

\section{3- Treatment}

Nandrolone Decanoate injection solution $(50 \mathrm{mg} / 1 \mathrm{ml})$ from Holland company is diluted to suitable concentration with Sesame oil, [17].

\section{4- Sperm morphology}

The sperm morphology smears to evaluate the sperm abnormalities by using Eosin/Nigrosin stain, one drop of $1.66 \%$ eosin and two drops of $10 \%$ of nigrosin was added to the suspension and were mixed by gentle agitations. Next, smears were prepared on clean slides, and allowed to dry at room temperature for 40-50 min fixatives by formalin or methanol. 400-600 sperms were examined in at least 6 fields of view covering the whole slide, [18].

\section{5- Sperm viability}

Sperm viability was evaluated as follows. A (20) $\mu$ l of "eosin and nigrosin suspension" were added into an equal volume of the sperm suspension. After 3-5 min of incubation at room temperature, slides were viewed by light microscope with magnification of 400. Dead sperms show to be pink and live sperms were not stained. In each sample, 400-600 Sperms were calculated and viability percentages were calculated,[19].

\section{6- Collection of Semen from Human}

Athletes were provide with disposable container, and semen were collected manually sperm viability and sperm morphology were evaluated. While the blood sample were taken from all athletic persons for detection of GPT, GOT,ALP, "FSH, LH and testosterone"[20].

\section{7- Result and Discussion}

Table 1: Effect of Nandralone on Liver Function Test on Young Athletites.

\begin{tabular}{|c|c|c|}
\hline Enzyme & Control athletic & Nandralone -Athletics \\
\hline GPT IU/L & $18 \pm 6.9$ & $22 \pm 5.8$ \\
& $\mathrm{a}$ & $\mathrm{a}$ \\
\hline GOT IU/L & $17 \pm 6.1$ & $\mathbf{2 0} \pm 5.5$ \\
& $\mathrm{a}$ & $\mathbf{5 5} \pm 8.5$ \\
\hline ALPIU/L & $49 \pm 9.2$ & $\mathrm{a}$ \\
\hline
\end{tabular}

Values are refer as Mean \pm SD.,

Compare with the other researches indicate statistical differences among two groups $(\mathrm{P}<0.05)$. similar latter indicate there is no significant test under $(\mathrm{P}<0.05)$.

The result revealed that athletic young person who injected with nandralone at least two months showed a minimum elevation in liver enzyme but there is no significant differences in GPT ,GOT, ALP. So that there is no significant differences at $(\mathrm{P}>0.05)($ table 1$)$. 


\section{LSD $=2.665$}

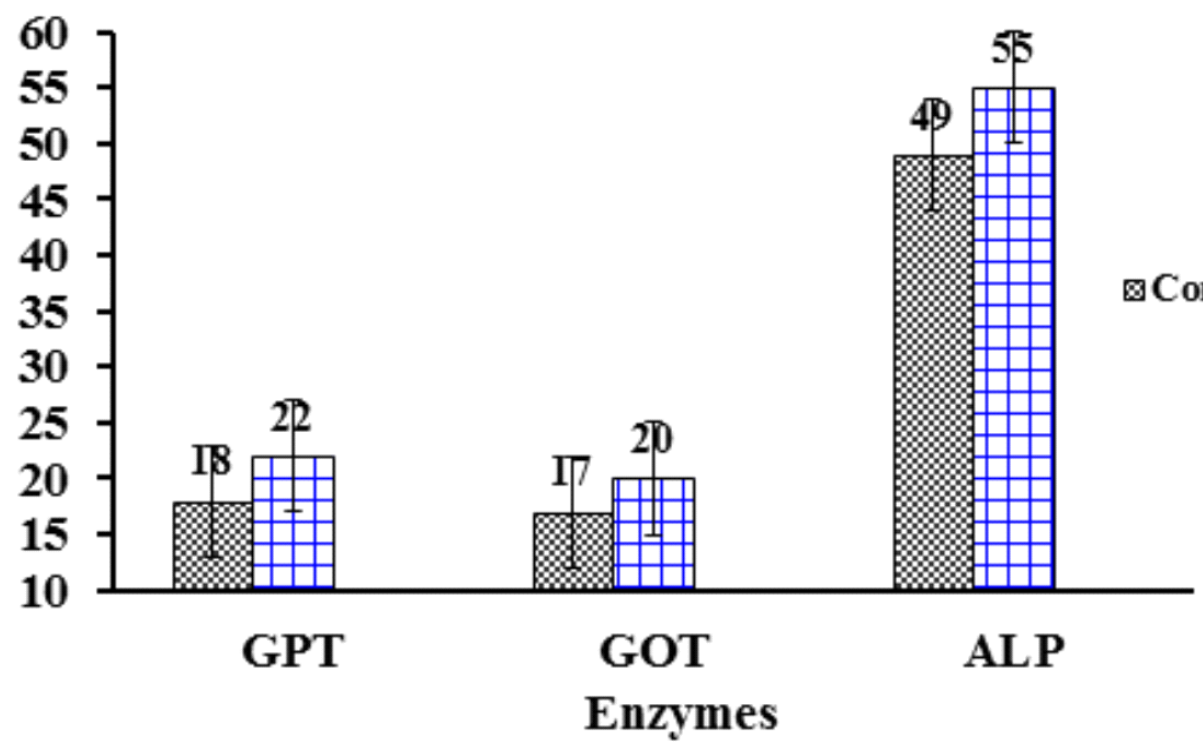

Diagram 1and 2 represent effect of Nandralone on liver enzyme and reproductive hormones .

Table 2:Effect of Nandralone on Reproductive Hormones for young Athletes.

\begin{tabular}{|l|l|l|}
\hline Hormones & Control athletic & Nandralone -Athletes \\
\hline FSH & $7.9 \pm 2.1 \mathrm{a}$ & $3 \pm 1.1 \mathrm{~b}$ \\
\hline L.H & $6.6 \pm 8.1 \mathrm{a}$ & $4.7 \pm 2.7 \mathrm{~b}$ \\
\hline Testosterone & $9.66 \pm 2.4 \mathrm{a}$ & $\mathbf{5 . 8 8} \pm 1.22 \mathrm{~b}$ \\
\hline
\end{tabular}

Values are refer as Mean \pm SD.

Letters expressed statistical differences among two groups $(\mathrm{P}<0.05)$. different latter indicate there is significant changes in hormonal value under $(\mathrm{P}<0.05)$.

The obtained listed in Table 2. The statistical analysis showed decreased levels of mean "serum FSH, LH and testosterone" in nandrolone decanoate injected group of male athletes in the experimental group (with a dosage of 25 $\mathrm{mg} / 3$ times a week during at least two month period compared with the counters in the athletes the control group. In nandrolone decanoate treated group, the mean serum FSH values were observed to sharply decrease to reach to $3 \pm 1.1$ MIU/L. While the control which recorded value of $7.9 \pm 2.1 \mathrm{MIU} / \mathrm{L}$. A significant decrease is also recorded in the "serum LH and testosterone" values from $4.7 \pm 2.7 \mathrm{mIU} / \mathrm{L}$ and $5.88 \pm 1.22 \mathrm{ng} / \mathrm{ml}$ respectively on the other side normal athletes remain within normal range to reach $6.6 \pm 8.1$ and $9.66 \pm 2.4$ respectively (Table 2 ). 
Availability of Sperm in Human

Chain 1

Chain 2

Mean - ${ }^{+}$SE

\section{availability of sperm in human}

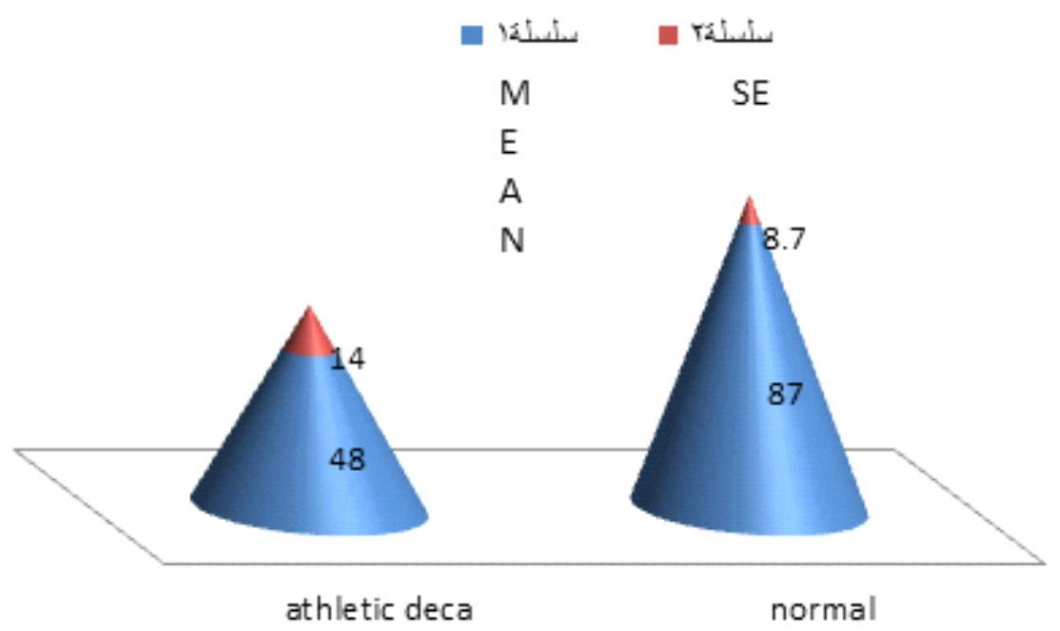

Abnormalities of Sperm

Chain1

Chain 2

Mean - ${ }^{+}$SE

\section{Abnormalites of sperm}

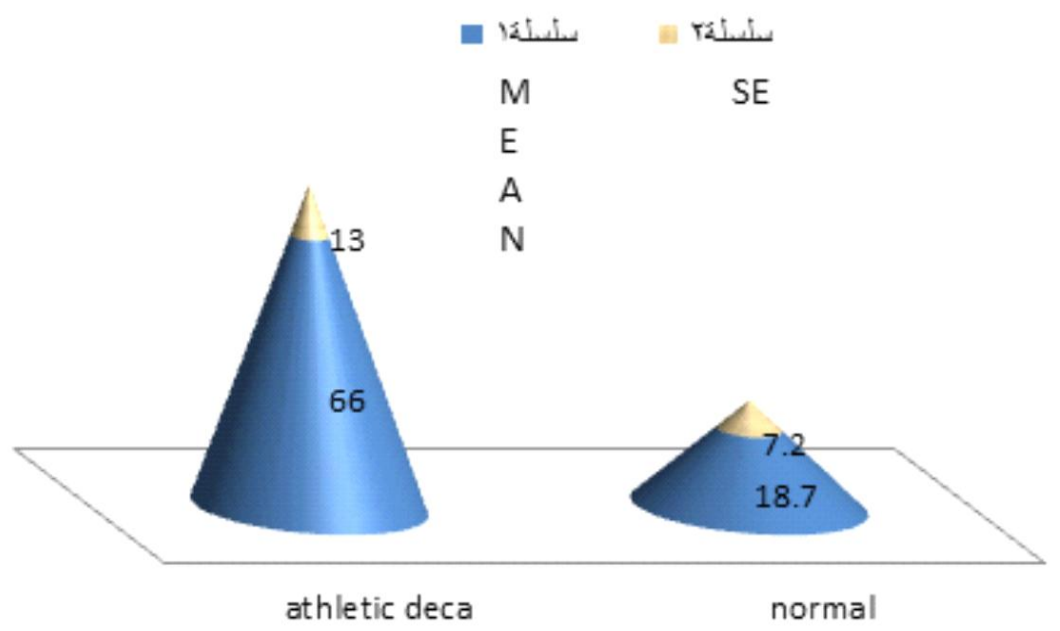


Diagram 3,4 represents the effect of nandralone on sperms, availability and abnormality. The statistical analysis showed significantly $(\mathrm{P}<0.05)$ decreased percent of mean sperm and a high percent of abnormalites in the experimental group.

The stimulator or inhibitor hormons release from specialized cell located in the hypothalamic nuclei to stimulate anterior pituitary gland (AP). Gonadotrophin release hormones. (Gn-RH) is one of hypothalamic regulatory hormone released in pulsatile manner to affect ( A.P) to secrete FSH and L.H, FSH hormones stimulate sartoli cell to release inhibin hormone that acts as a synergism in process of spermatogenesis. FSH also produces androgen binding protein which help to maintains enough level testosterones in testes. Leydig cell stimulate by L.H to secrete testosterone which is very important to regulate spermatogenesis in semniferous tubules[21],[22]. The negative feed back for testosteron act to block L.H secretion, this process will occur after administrating synthetic hormones so that sensitivity to high level to testosterone synthetic lead to defect in synthesis process of spermatogenesis to produce deformity and dead cell of sperm, [19],[5],[23]. "Indicate that injection with intramuscular of supra physiological doses of Nandrolone Decanoate to male albino mice with a dosage of $2.5 \mathrm{mg} /$ week for 90 showed gradual decline from $14.2 \pm 0.51$ $\mathrm{mIU} / \mathrm{ml}$ on 20 th day to $8.7 \pm 0.29 \mathrm{mIU} / \mathrm{ml}$ on 90 th day of treatment". Also recorded the gradual decrease was also recorded in the serum $\mathrm{LH} 17.8 \pm 0.73 \mathrm{mIU} / \mathrm{ml}$ on 30th day to $10.4 \pm 0.57 \mathrm{mIU} / \mathrm{ml}$ on 90th day, while the sharp decrease in testosterone hormone showed at beginning of 20th day to record $1.92 \pm 0.07 \mathrm{ng} / \mathrm{ml}$ on to $1.09 \pm 0.08 \mathrm{ng} / \mathrm{ml} \mathrm{on} 90^{\text {th }}$ rather than that of control group $2.09 \pm 0.08 \mathrm{ng} / \mathrm{ml}$. Our study concord with, [24] also showed marked reduction testosterone concentration in male rats injected with Testosterone at a dose of $400 \mathrm{mg} / \mathrm{kg}$ from normal range $0.81+$ 0.014 to $0.30+0.0067(\mathrm{ng} / \mathrm{ml}), 0.26+0.009(\mathrm{ng} / \mathrm{ml})$. The study also was agreed with much research work which reveal increase in teratozoospermia accompanied with high percent of dead sperms in mice injected with $15 \mathrm{mg} / \mathrm{kg}$ three times a week. These investigations also in agreement with [19] reported that the daily administration of rats with dianabol at dose $40 \mathrm{mg} / \mathrm{kg}$ daily increase of teratozoospermia and increased dead sperms with high percent of teratozoospermia. administration of nandralone in low dose $3 \mathrm{mg} / \mathrm{kg}$ and high dose $10 \mathrm{mg} / \mathrm{kg}$ for 14 weeks showed significant precentag of oligospermia $(31.4 \pm 5.9 \times 106 / \mathrm{ml})$ and high $(44.7 \pm 5.9 \times 106 / \mathrm{ml})$ and $(116.01 .1 \mathrm{x} 106 / \mathrm{ml})$, percentage of progressively motility $(39.24 .1 \%$ and $19.4 \pm 3.1 \%$, respectively).Moreover there is significantly defected DNA of rat treated with Nandrolone Decanoate. about (72.3\% and 53.3\%), respectively and (19.7\%) for health rats .[1], demonstrate that's male rats injected Nandrolone Decanoate $(10 \mathrm{mg} / \mathrm{kg} /$ weekly) for 8 weeks reveal increases in germ cell apoptosis and destroyed testicular tissue under using TUNEL and transmission electron microscopy, [25],[17].

\section{Reference:}

[1] Shokri Saeed .et al.,"Exercise and Supraphysiological Dose of Nandrolone Deconoate Increase Apoptosis in Spermatogenic Cells. Nordic Pharmacological Society”. Basic \& Clinical Pharmacology \& Toxicology, 106, 324-330. 2009.

[2] Thiblin I and Petersson A. "Pharmacoepidemiology of anabolic androgenic steroids: a review".Fundam Clin Pharmacol., 19: 27-44.2005.

[3] Hall RC, Hall RC. “Abuse of supraphysiologic doses of anabolic steroids”. South Med J;98:550-5. 2005.

[4] Gold, J. et al.," Effects of nandrolone decanoate compared with placebo or testosterone on HIV-associated wasting",HIV Medicine ., 7: 146-155. 2006.

[5]Purkayastha Sravonee and Rita Mahanta."Effect of Nandrolone Decanoate on SerumFSH, LH and Testosterone Concentration in Male Albino Mice". World J Life Sci. and Medical Research;2:123. 2012.

[6] Carmo,A. C. "Clastogenicidade lastogenicidade E/OU Aneugenicidade do Hormonio Androgenico nandrolona (DECA-DURABOLIN®) EM Camundongos”. Instituto de Biociência. 2009.

[7] Kayaalp, SO.,"Rasyonel tedavi yönünden tıbbi farmakoloji, 11”. Baskl. Ankara, Feryal Matbaa.1126-57. 2005.

[8] Gül, M.’Testosteron hormon seviyesinin koroneryavaş akım ile ilişkisi”. İstanbul, Dr. SiyamiErsek Göğüs Kalp Damar Cerrahisi Eğitim veAraştırma. 2008.

[9]Furman, BL.”The Comprehensive Pharmacology Reference, EnnaSJ, Bylund DB. Eds”, N.York, Elsevier Inc; 1-5. 2007.

[10] Tasgin and Haliloglu. Seyfullash. The aministraztion of nandralone deconate may cause multiple organ failure Science, Movement and Health .2007.

[11] Gårevik Nina .Quantitative Influence of Exogenous Androgens on Serum Lipid Profile and Endocrine Functions.ISBN., 4:978-991. 2013. 
[12] Sader MA,et al.," Androgenic anabolic steroids and arterial structure andfunction in male bodybuilders". J Am Coll Cardiol; 37: 224-230. 2001.

[13]Karila, Tuomo."Adverse effects of anabolic androgenic steroids on thecardiovascular, metabolic and reproductive systemsof anabolic substance abusers", ACADEMIC DISSERTATION collage of Medicine of the Universityof Helsinki .,1-66. 2003.

[14]Jonathan Isaacs, M.D., Joseph Feher, Ph.D., Mary Shall, Ph.D.,Scott Vota, D.O.,Michael A. Fox, Ph.D.,5 Satya Mallu, M.D., Ashkon Razavi , M.D.,1 Ilvy Friebe, M.D.,Sagar Shah, B.S., and Nathalie Spita” Effects of nandrolone on recovery after neurotization ofchronically denervated muscle in a rat model". J Neurosurg.,5:1-10. 2013.

[15]Chuffa, L, et al.,"Nandrolone Decanoate and PhysicalEffort: Histological and Morphometrical Assessment in Adult Rat Uterus", THE ANATOMICAL RECORD.,294:335-341 . 2011.

[16]Adel M,et al., "Licorice: A possible anti-I nflammatory and anti-ulcer drug”. AAPS PharmSciTech; 6. 74-82. 2005.

[17]Kindlundh A, et al.,." Increased dopamine transporter density in the male rat brain following chronic nandrolone decanoate administration". Neurosci Lett. .,12: 131-4. 2004.

[18] Halberg,M.anabolic androgen steroid effect on neuropeptide system in the rats brain. PHD thesi ,university of Uppsala , faculty of pharmacy, Sweden., 11-55. 2005.

[19] Jassim, Adnan, et al., "Study of the testicular damage induced by dianabol and its effect on morphological and histological changes in albino male rats". IOSR Journal of Agriculture and Veterinary Science.,8 : 24-32. 2015.

[20]Kindlundh AMS, et al., "Factors associated with adolescent of dopingagents:anabolicandrogenicsteroids".Addiction .94:543-553. 1999.

[21]Caires, Kyle C; et al. "Vascular endothelial growth factor regulates germ cell survival during establishment of spermatogenesis in the bovine testis".,Reproduction 138., 667-677. 2009.

[22]Rana,Basabi."Neuroendocrine Pharmacology:Hypothalamic and Pituitary Hormones". Pharmacology \& Therapeutics, Chapter 37. 2013.

[23] Andreato Leonardo Vidal,et al.,"Use of the anabolic steroid nandrolone decanoate associated tostrength training in Wistar rats”.,Acta Scientiarum. Biological Sciences Maringá.,3: 283-291. 2007.

[24] Hijazi.M.M. " study of the testicular atrophy induced by Androgenic Anabolic steroids and its effect on histology and hormonal level in albino rats”,PhD thesis, University of KARACHI.,109-117. 2009.

[25] Kamei J, Saitoh A, Asano T. "Pharmacokinetic and pharmacodynamic profiles of the antitussive principles of Glycyrrhizae radix (licorice), a main component of the Kampo preparation Bakumondo-to (Mai-men-dong-tang)". Eur J Pharmacol .,507: 163-168. 2005.

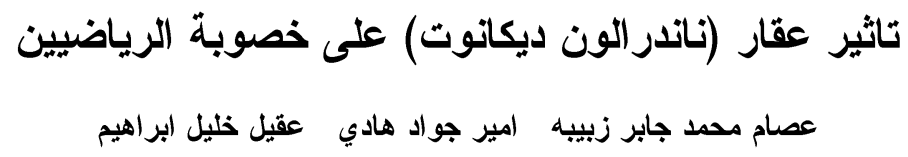

يعتبر عقار المنشطات الاندروجينية (AAS) واسع الاستخدام لدى الكثير من الرياضيين وذلك لبناء العضلات والمظهر الخارجي من خلال هذه

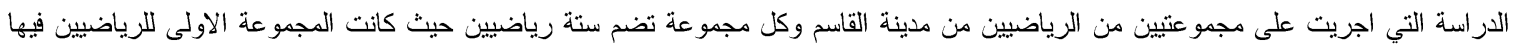

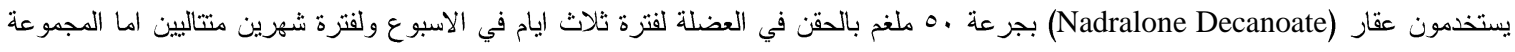

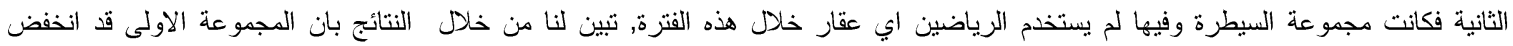

مسنوى انزيمات الكبد) لليهم بدون وجود فوارق احصائية معنوية, مع انخفاض بمستوى هرمون (GPT,GOT,ALP) (LH ,FSH, Testesterone)

$$
\text { مقارنة مع مجمو عة السيطرة. }
$$$$
\text { الكلمات الدالة: ديكانوت ناندر الون, رياضيين، خصوبة. }
$$ 